\title{
First report of the Flowerpot Blindsnake, Indotyphlops braminus (Daudin, 1803), from La Désirade (Guadeloupe Archipelago, the French West Indies)
}

\author{
Olivier Lorvelec ${ }^{1,2}{ }^{*}$, Joël Berchel ${ }^{3}$, and Nicolas Barré ${ }^{2}$ \\ 'INRA, UMR0985 Écologie et Santé des Écosystèmes, Campus de Beaulieu, 35042 Rennes, Bretagne, France. \\ ${ }^{2} \mathrm{AEVA}$, Association pour l'Étude et la protection des Vertébrés et végétaux des petites Antilles, 97170 Petit Bourg, Guadeloupe, France. \\ ${ }^{3}$ Association Titè, Réserve Naturelle Nationale des îles de la Petite Terre, 97127 La Désirade, Guadeloupe, France. \\ ${ }^{*}$ Corresponding author (Olivier.Lorvelec@rennes.inra.fr) \\ Date of publication: 17 May 2016. \\ Citation: Lorvelec O, Berchel J, Barré N (2016) First report of the Flowerpot Blindsnake, Indotyphlops braminus (Daudin, 1803), from La \\ Désirade (Guadeloupe, the French West Indies). Caribbean Herpetology 55:1-2.
}

We report, for the first time, the presence of the Flowerpot Blindsnake, Indotyphlops braminus (Daudin, 1803), on La Désirade (Guadeloupe Archipelago) in the Lesser Antilles. On July 2014, three individuals were found by one of us (JB) inside a pile of soil from earthworks near a house in an inhabited area southwest of the village of Baie-Mahault $(16.3246,-61.0269$, elevation $20 \mathrm{~m})$. It is a typical situation for this species. Two of the snakes were collected and remained for a year in denatured alcohol before being preserved in $70 \%$ ethanol. Both have the same total length of $142 \mathrm{~mm}$. The specimens have an unnaturally pale coloration for that normally dark species (Fig. 1).

Indotyphlops braminus is parthenogenetic and has a wide distribution, and may have originated in India (Hedges et al. 2014). Its introduction in the Lesser Antilles seems to be recent, with the first report from Anguilla (Censky \& Hodge 1997). Since then, the species has been recorded from several other islands (Henderson \& Breuil 2012, Powell et al. 2011, 2013), including the two main islands of Guadeloupe (Basse-Terre and Grande-Terre; Breuil \& Ibéné 2008). Our report of $I$. braminus from La Désirade is also the first one for a surrounding island (islet) of Guadeloupe. The presence of the species should be investigated on the other islets of Guadeloupe.

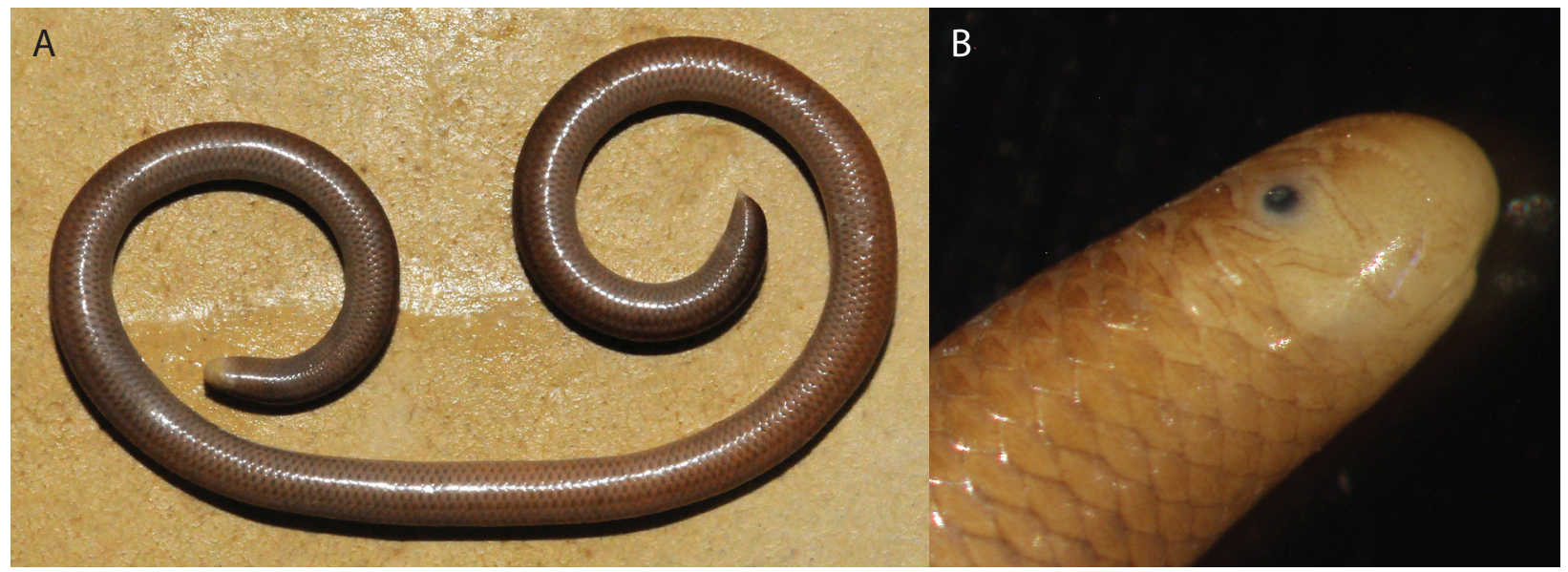

Figure 1. Body (A) and head (B) of a preserved specimen of the Flowerpot Blindsnake, Indotyphlops braminus, from La Désirade (Guadeloupe Archipelago).

\section{Acknowledgements}

We thank S. Blair Hedges (Center for Biodiversity, Temple University, Philadelphia) for his assistance in the species identification, the Direction de l'Environnement, de l'Aménagement et du Logement de la Guadeloupe (DEAL Guadeloupe), especially Béatrice Galdi and Fabien Barthelat, for authorization to transport both specimens to 
the USA, and the Association AEVA (Guadeloupe), especially Claudie Pavis, for having established a scientific partnership agreement between the Association AEVA and the Center for Biodiversity. We thank Thierry Frétey (Association RACINE, Rennes, France) for his assistance in literature search and review of the manuscript.

\section{References}

Breuil M, Ibéné B (2008) Les hylidés envahissants dans les Antilles françaises et le peuplement batrachologique naturel. Bulletin de la Société Herpétologique de France, 125, 41-67.

Censky EJ, Hodge K (1997) Geographic distribution: Ramphotyphlops braminus. Herpetological Review, 28, 210.

Daudin FM (1803) Histoire Naturelle, Générale et Particulière des Reptiles. Tome Septième. F. Dufart, Paris, France, $436 \mathrm{pp}$.

Hedges SB, Marion AB, Lipp KM, Marin J, Vidal N (2014) A taxonomic framework for typhlopid snakes from the Caribbean and other regions (Reptilia, Squamata). Caribbean Herpetology, 49, 1-61.

Henderson RW, Breuil M (2012) Lesser Antilles, pp. 148-159. In: Island lists of West Indian amphibians and reptiles, Powell R, Henderson RW (eds), Bulletin of the Florida Museum of Natural History, 51, 85-166.

Powell R, Henderson RW, Farmer MC, Breuil M, Echternacht AC, van Buurt G, Romagosa CM, Perry G. (2011). Introduced amphibians and reptiles in the greater Caribbean: patterns and conservation implications, pp. 63-143. In: Conservation of Caribbean Island Herpetofaunas. Volume 1: Conservation Biology and the Wider Caribbean, Hailey A, Wilson BS, Horrocks JA (eds), Brill, Leiden, The Netherlands.

Powell R, Henderson RW, Perry G, Breuil M, Romagosa CM (2013) Introduced amphibians and reptiles in the Lesser Antilles, pp. 74-107. In: Biodiversité Insulaire: la Flore, la Faune et l'Homme dans les Petites Antilles, Vernier JL, Burac M (eds). Actes du Colloque international, Schoelcher, 8-10 November 2010, Direction de l'Environnement, de l'Aménagement et du Logement de la Martinique, Université des Antilles et de la Guyane, Schoelcher, Martinique. 